\title{
Membrane Binding and Release of Bacillus subtilis DNA as a Function of the Cell Cycle
}

\author{
By NAOMI SANDLER* AND ALEX KEYNAN \\ Section of Developmental and Molecular Biology, Department of Biological Chemistry, \\ The Hebrew University of Jerusalem, Institute of Life Sciences, 91904 Jerusalem, Israel
}

(Received 26 August 1987; revised 21 December 1987)

\begin{abstract}
The presence of origin-region DNA in preparations containing bacterial cell wall and cytoplasmic membrane is well established, but little is known about the relationship between this association and events of the cell cycle. We have observed, during renewed growth of stationaryphase cultures of Bacillus subtilis, an association of DNA, including newly synthesized regions, with a specific region of the plasma membrane. Attachment was transitory, occurring once per replication cycle, and was prevented by inhibitors of cell wall synthesis.
\end{abstract}

\section{INTRODUCTION}

It was suggested by Jacob et al. (1963) that the bacterial chromosome is attached in some way to the cell surface, providing a means of regulating both initiation of DNA replication and chromosome segregation. There have been many subsequent reports confirming the presence of origin-region DNA in preparations containing membrane of Bacillus subtilis and Escherichia coli (Sueoka \& Quinn, 1968; Snyder \& Young, 1969; Fielding \& Fox, 1970; Yamaguchi et al., 1971; Nicolaidis \& Holland, 1978; Sargent et al., 1983; Sargent \& Bennett, 1985, 1986; Bone et al., 1985 ), and also a report that both cytoplasmic membrane and cell wall of $B$. subtilis are found in association with early replicating chromosomal loci (Doyle et al., 1980).

The existence of a physical link between origin DNA and the cell surface has thus been established, as has the existence of a connection between association of DNA with the cytoplasmic membrane and initiation of replication (Winston \& Sueoka, 1980). However, little is known of the dynamic aspects of this connection despite extensive investigation of the relationship between DNA and the cell surface. The expected dependence on the cell cycle of the association between origin DNA and the cytoplasmic membrane has not been established (Winston \& Sueoka, 1982), and only physical association between origin DNA and the cell wall has been observed.

On lysis of protoplasts prepared from cells at any stage of growth, most of the DNA remains in association with membrane. We have fractionated the membrane by allowing sonicated membrane preparations to bind to cadmium lauroylsarcosine, and then washing off subfractions with increasing concentrations of $\mathrm{KCl}$ and deoxycholate, according to the method developed by Tremblay et al. (1969) and by Daniels (1971). When the DNA-binding fractions of the membrane were isolated, we observed distinct differences in the amount of membrane-fractionassociated DNA of cells taken from synchronous cultures at various times during the DNA replication cycle.

Abbreviations: CAM, chloramphenicol; GIcNAc, $N$-acetyl-D-glucosamine; TMK, Tris/magnesium acetate/ $\mathrm{KCl}$ buffer. 


\section{METHODS}

Organism and growth conditions. B. subtilis $168 \operatorname{trpC}$ was used in all experiments. The strain was obtained from Professor J. Mandelstam. Cells were grown in brain heart infusion broth (BHI; Difco) at $35-37^{\circ} \mathrm{C}$.

Initiation of DNA replication. Synchronous growth and initiation of DNA replication was induced by transfer of stationary-phase cells to fresh medium (Sandler \& Keynan, 1979, 1981). This method has also previously been used successfully by others (Masters et al., 1964; Paulton, 1971; Yoshikawa \& Sueoka, 1963). Dilutions varied from one to ten times the original culture volume, depending on the desired final cell concentration. In all cases, reasonable synchrony of initiation of DNA replication was obtained, as determined by the method described below.

DNA synthesis was measured as incorporation of $\left[{ }^{3} \mathrm{H}\right]$ thymidine or $\left[{ }^{14} \mathrm{C}\right]$ thymidine, in the presence of uridine, according to the method of Budman \& Pardee (1967). Sample treatment was exactly as described below for measurement of cell wall synthesis.

For measurement of the number of chromosomes in a cell culture which had initiated replication, residual DNA synthesis was determined while further initiation was prevented by inhibition of protein synthesis. This method is based on the fact that protein synthesis is required for initiation of DNA replication but not for elongation (Lark et al., 1963). The determination was done by transferring portions of the cultures to test tubes containing labelled thymidine $\left(10 \mu \mathrm{Ci}\left[{ }^{3} \mathrm{H}\right]\right.$ thymidine $\mathrm{ml}^{-1}$ or 1.4 or $2 \cdot 8 \mu \mathrm{Ci}\left[{ }^{14} \mathrm{C}\right]$ thymidine $\left.\mathrm{ml}^{-1}\right)\left(370 \mathrm{kBq}\left[{ }^{3} \mathrm{H}\right]\right.$ thymidine $\mathrm{ml}^{-1}$ or 52 or $104 \mathrm{kBq}\left[{ }^{14} \mathrm{C}\right]$ thymidine $\left.\mathrm{ml}^{-1}\right)$ and unlabelled uridine $\left(250 \mu \mathrm{g} \mathrm{ml}^{-1}\right)$, as well as $100 \mu \mathrm{g}$ chloramphenicol (CAM) $\mathrm{ml}^{-1}$ (Sigma) to inhibit protein synthesis. The radioactivity associated with the cells was measured immediately, and again after $120 \mathrm{~min}$ at $37^{\circ} \mathrm{C}$.

Cell wall synthesis. Cell wall synthesis was measured as incorporation of $N$-acetyl-D-[1-14 C]glucosamine $\left(\left[{ }^{14} \mathrm{C}\right] \mathrm{GlcNAc}\right.$; Amersham). At intervals during incubation of cells with $\left[{ }^{14} \mathrm{C}\right] \mathrm{GlcNAc}\left(24 \mu \mathrm{M}, 1 \cdot 3 \mu \mathrm{Ci} \mathrm{ml}{ }^{-1}\right)$, duplicate $40 \mu \mathrm{l}$ samples were transferred from cultures to $2.0 \times 2.5 \mathrm{~cm}$ pieces of Whatman $3 \mathrm{MM}$ chromatography paper, washed twice with cold $5 \%(\mathrm{w} / \mathrm{v}) \mathrm{TCA}$ and twice with cold $70 \%(\mathrm{w} / \mathrm{v})$ ethanol. After drying the papers, radioactivity was counted in $4.5 \mathrm{ml}$ Scintillator 299 (Packard). Cell wall synthesis was inhibited by addition of $3 \mu \mathrm{g}$ vancomycin $\mathrm{ml}^{-1}$ (Sigma).

Preparation of membrane fractions and determination of associated DNA. Membranes were prepared and fractionated by the method of Daniels (1971) with several modifications. Each sample for membrane preparation generally contained the equivalent of $5 \mathrm{ml}$ of culture of $\mathrm{OD}_{600} 7 \cdot 5-10 \cdot 0$. The samples usually consisted of $90 \%$ unlabelled carrier cells and $10 \%$ of the labelled cells being investigated, filtered together on $4.7 \mathrm{~cm}$ diameter membrane filters $(0.45 \mu \mathrm{m}$ pore size).

In most experiments, the filters were transferred to $10 \mathrm{ml}$ Tris/magnesium acetate $/ \mathrm{KCl}$ buffer (TMK) (0.01 MTris $/ \mathrm{HCl}$, pH 7.4, 0.01 M-magnesium acetate, $0 \cdot 1 \mathrm{M}-\mathrm{KCl}$ ) containing $0.58 \mathrm{M}$-sucrose and $100 \mu \mathrm{g} \mathrm{CAM} \mathrm{ml} \mathrm{m}^{-1}$ and frozen for later preparation of membranes. After thawing, $250 \mu \mathrm{g}$ lysozyme $\mathrm{ml}^{-1}$ (Sigma) was added and the samples were incubated without shaking at $37^{\circ} \mathrm{C}$ until rod forms were no longer visible (about $30 \mathrm{~min}$ ). The pelleted protoplasts were lysed by addition of $10 \mathrm{ml}$ cold TMK (without sucrose and CAM) and vortexing, then centrifuged and washed four times with $10 \mathrm{ml}$ volumes of cold TMK. For each wash the pellets in TMK were repeatedly drawn into and expelled from a Pasteur pipette. After the final TMK wash, each sample was frozen in $3 \mathrm{ml}$ distilled water, and, on the following day, sonicated for $15 \mathrm{~s}$ in $30 \mathrm{ml}$ plastic tubes. Under the conditions of these experiments, a $15 \mathrm{~s}$ sonication of the cell lysate allowed maximum recovery of DNA. Omission of sonication or sonication for more than $15 \mathrm{~s}$ lowered subsequent recovery of both protein and DNA in the membrane fractions.

The sonicates were added to $10 \mathrm{ml} 0.05 \mathrm{M}-\mathrm{CdCl}_{2}$ plus $10 \mathrm{ml} 0.05 \mathrm{M}$-sodium lauroylsarcosine and left on ice for approximately $1 \mathrm{~h}$. For fractionation, each sample was poured onto a $4.7 \mathrm{~cm}$ diameter filter $(0.45 \mu \mathrm{m}$ pore size $)$ and washed with two $5 \mathrm{ml}$ portions of distilled water, followed by four $5 \mathrm{ml}$ portions of $0 \cdot 1 \mathrm{M}-\mathrm{Tris} / \mathrm{HCl}, \mathrm{pH} \mathrm{7 \cdot 4}$ (fraction 1), the same buffer containing $0.1 \mathrm{M}-\mathrm{KCl}$ (fraction 2), or buffer plus $0.2 \mathrm{M}-\mathrm{KCl}$ (fraction 3). Where specified, fractionation was continued with higher concentrations of $\mathrm{KCl}$ and/or sodium deoxycholate. TCA was added to the fractions to a final concentration of $10 \%(\mathrm{w} / \mathrm{v})$, and they were left overnight in the cold. The precipitates were collected on membrane filters, washed with $5 \%(\mathrm{w} / \mathrm{v})$ TCA and $70 \%(\mathrm{w} / \mathrm{v})$ ethanol, and radioactivity was counted in $4.5 \mathrm{ml}$ Scintillator 299 . Alternatively, small portions of the samples were analysed for radioactivity directly.

Agarose gel electrophoresis. Agarose gel electrophoresis of the DNA associated with membrane fractions was done according to Maniatis et al. (1982).

\section{RESULTS}

Association of DNA with a specific fraction of the cytoplasmic membrane

We labelled DNA either during or after initiation of replication, by diluting a stationaryphase culture of $B$. subtilis 1 in 10 to induce synchronous growth, and then immediately dividing 

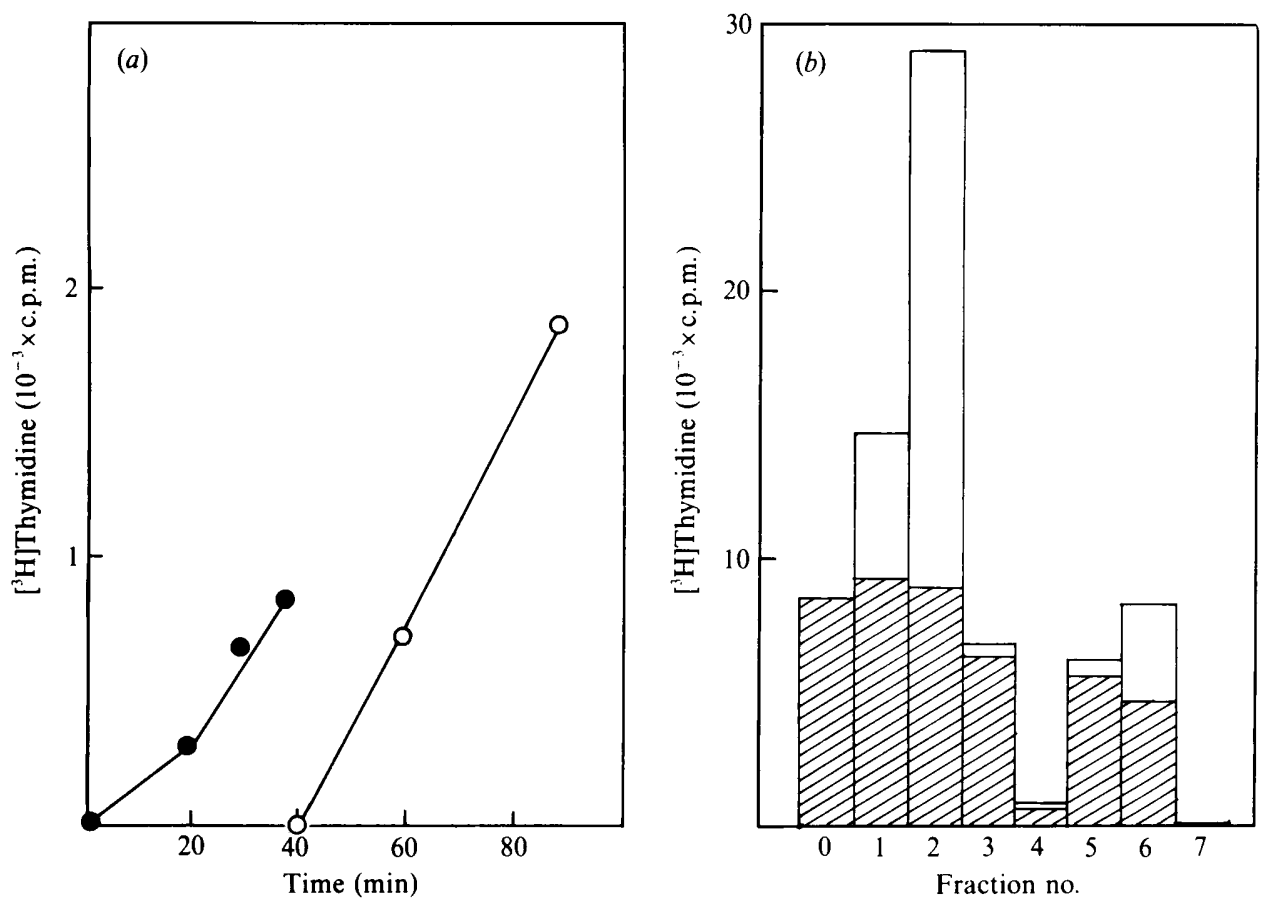

Fig. 1. Association of DNA with membrane fractions. A stationary-phase culture was diluted 1 in 10 with fresh BHI and divided into two equal portions for incubation. One portion (sample I) was labelled with $\left[{ }^{3} \mathrm{H}\right]$ thymidine from time 0 of incubation $(O)$, and the other (sample E) from $40 \mathrm{~min}(\mathrm{O}) .(a)$ $\left[{ }^{3} \mathrm{H}\right]$ Thymidine incorporated into $0.04 \mathrm{ml}$ culture. The counts were normalized by subtraction of the time 0 blank. (b) $\left[{ }^{3} \mathrm{H}\right]$ Thymidine associated with membrane fractions eluted from cadmium

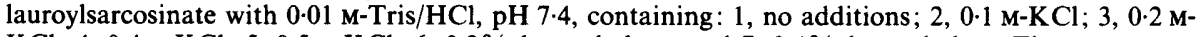
$\mathrm{KCl} ; 4,0.4 \mathrm{M}-\mathrm{KCl} ; 5,0.5 \mathrm{M}-\mathrm{KCl} ; 6,0.2 \%$ deoxycholate; and $7,0.4 \%$ deoxycholate. The open areas represent the membrane-associated counts of sample I, incubated with label from time 0 . The hatched areas represent the membrane-associated counts of sample E, incubated with label from $40 \mathrm{~min}$.

it into two equal portions for incubation. One portion was exposed to $\left[{ }^{3} \mathrm{H}\right]$ thymidine during the first $40 \mathrm{~min}$ of incubation, which included a period of about $20 \mathrm{~min}$ prior to initiation of DNA replication and a subsequent 20 min during which initiation of replication was completed in the culture and elongation began. The progress of initiation was estimated by determining the time of escape of incorporation of $\left[{ }^{3} \mathrm{H}\right]$ thymidine from inhibition by CAM (Lark et al., 1963). In our strain of $B$. subtilis, the method of diluting a stationary-phase culture produces reasonably good synchrony of chromosome replication for at least one cell cycle, as has been shown previously (Sandler \& Keynan, 1981), and as in Figs 2 and 4.

After the first $40 \mathrm{~min}$ of incubation, the cells were filtered and membrane preparation was begun as described in Methods. The DNA of this portion of the original culture (sample I) was considered to be labelled at the replication origin and approximately the first one-third of the chromosome.

$\left[{ }^{3} \mathrm{H}\right]$ Thymidine was added to the second half of the original culture after the first $40 \mathrm{~min}$ of incubation, and incubation in the presence of label was continued for another $50 \mathrm{~min}$. CAM was added together with the $\left[{ }^{3} \mathrm{H}\right]$ thymidine, to prevent any further initiation of DNA replication. This sample (sample E) thus contained DNA labelled only in regions distant from the replication origin, taken from cells in the process of completing a DNA replication cycle.

The values of acid-precipitable radioactivity associated with the membrane fractions prepared from the two halves of the original culture were compared, and it was found that approximately twice as much radioactivity was associated with the membrane fractions of the cells which had incorporated label during initiation of DNA replication, and were harvested 


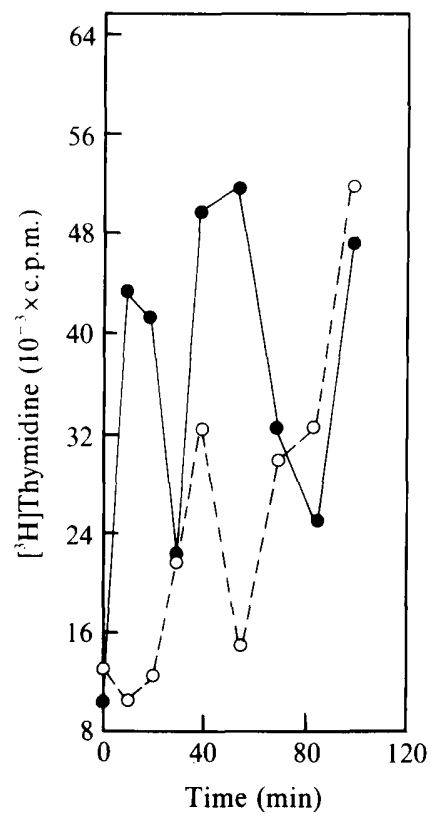

Fig. 2

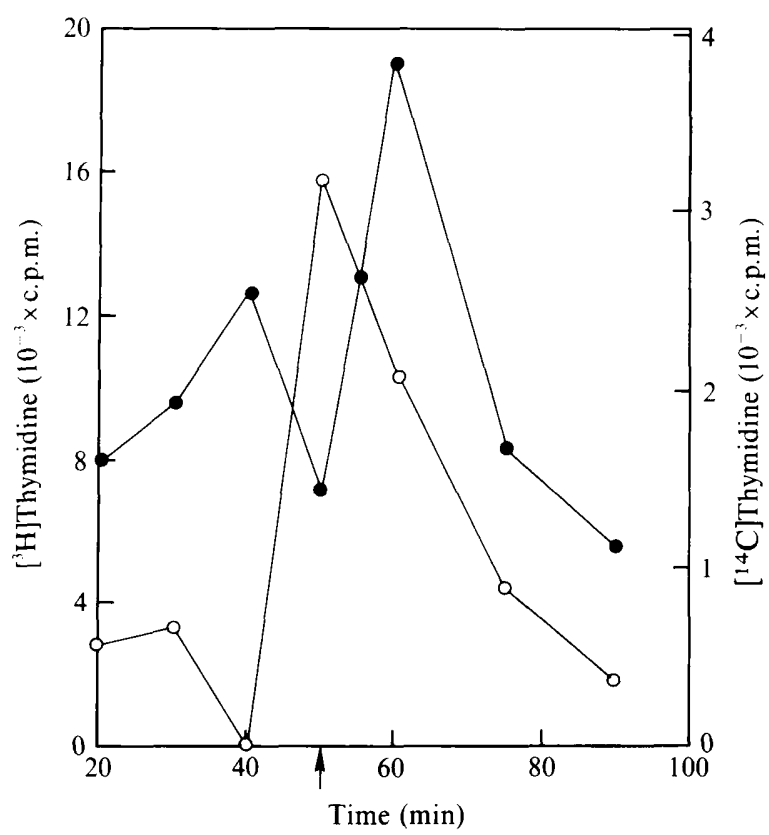

Fig. 3

Fig. 2. DNA association with membrane fraction 2 as a function of the cell cycle. A stationary-phase culture uniformly labelled by overnight growth in the presence of $\left[{ }^{3} \mathrm{H}\right]$ thymidine $\left(8 \mu \mathrm{Ci} \mathrm{ml} l^{-1}\right)$ and uridine $\left(250 \mu \mathrm{g} \mathrm{ml}^{-1}\right)$ was filtered and the cells transferred to fresh BHI without label. At intervals after the beginning of incubation, samples were removed for determination of radioactivity associated with membrane fraction $2(O)$, and additional samples were taken for measurement of incorporation of $\left[{ }^{3} \mathrm{H}\right]$ thymidine in the presence of CAM, as described in Methods $(\mathrm{O})$.

Fig. 3. Comparison of association with membrane fraction 2 of pre-existing and newly synthesized DNA. A stationary-phase culture uniformly labelled with $\left[{ }^{14} \mathrm{H}\right]$ thymidine was filtered and the cells transferred to ten times the original volume of fresh $\mathrm{BHI}$ containing $\left[{ }^{3} \mathrm{H}\right]$ thymidine. Portions were removed at intervals during incubation for determination of radioactivity associated with membrane fraction 2 due to ${ }^{3} \mathrm{H}$-labelled DNA (newly synthesized, $O$ ) and ${ }^{14} \mathrm{C}$-labelled DNA (pre-labelled DNA, -), and for measurement of incorporation of $\left[{ }^{3} \mathrm{H}\right]$ thymidine in the presence of CAM, as described in Methods. Arrow indicates escape of DNA replication from inhibition by CAM.

relatively early in the cell cycle (sample I). This was in spite of the fact that the total incorporation of $\left[{ }^{3} \mathrm{H}\right]$ thymidine by the cells of sample I was only half that of the cells of sample ' $E$ ', which were labelled during the latter part of the DNA replication cycle.

The major difference between the two halves of the culture was found in membrane fraction 2 , which is dissociated from cadmium lauroylsarcosinate by $0 \cdot 1 \mathrm{M}-\mathrm{KCL}$. The ratio of fraction 2 radioactivity of samples $\mathrm{I}$ and $\mathrm{E}$ was approximately $3: 1$. In sample $\mathrm{E}$ there was no peak of radioactivity in fraction 2 , compared with the other membrane fractions. In sample ' $I$ ', however, there was a very distinct peak in fraction 2 (Fig. $1 a, b$ ). While a small amount of DNA was associated with membrane fractions 5 and 6 , there was little difference in the amount of DNA associated with these fractions at the two different stages of the chromosome replication cycle.

\section{DNA association with membrane fraction 2 is a function of the cell cycle}

In subsequent experiments, we grew $B$. subtilis cells to stationary phase in the presence of $\left[{ }^{3} \mathrm{H}\right]$ thymidine, and induced synchronous renewal of growth by transferring the uniformly labelled cells to fresh medium without label. At various times after the beginning of incubation, samples were removed for membrane preparation and isolation of membrane fractions. At the same time, portions of the culture were removed for measurement of the amount of DNA synthesis in the presence of CAM, as a measure of the progress of initiation of DNA replication. 
The association of radioactivity with membrane fraction 2 was cyclic, with apparently one peak per round of DNA replication. In the first round, at least, association of pre-labelled DNA with fraction 2 increased before the beginning of initiation, and began to decline before initiation was completed in the culture (Fig. 2). The relationship between peak DNA association and initiation of replication was consistently reproducible, although the time required for initiation of replication varied somewhat, depending on the culture, the time elapsed during filtration, and the temperature of the fresh medium at the time of dilution. The radioactivity associated with fraction 2 at the peak generally represented approximately $5 \%$ of the total DNA of the culture.

\section{Association of pre-existing and newly synthesized DNA with membrane fraction 2}

The associations with the cytoplasmic membrane of pre-existing and newly synthesized DNA were compared in a double-label experiment. Cells were grown to stationary phase in the presence of $\left[{ }^{14} \mathrm{C}\right]$ thymidine, then filtered and suspended in fresh medium containing $\left[{ }^{3} \mathrm{H}\right]$ thymidine. Samples were removed periodically for membrane preparation and also for measurement of DNA synthesis in the presence of CAM. After $40 \mathrm{~min}$ incubation in the presence of $\left[{ }^{3} \mathrm{H}\right]$ thymidine, an excess of unlabelled thymidine was added to prevent further incorporation of label.

The peaks of radioactivity associated with membrane fraction 2 occurred at different times for the two isotopes during the first hour of incubation. Also, prior to escape of DNA replication from inhibition by CAM, the amount of newly synthesized, ${ }^{3} \mathrm{H}$-labelled DNA associated with membrane fraction 2 increased while the ${ }^{14} \mathrm{C}$ counts, representing previously existing membrane-bound DNA, decreased (Fig. 3).

\section{Incorporation of GlcNAc as a function of the cell cycle}

We reported that initiation of DNA replication is dependent on cell wall synthesis during renewed growth of stationary-phase cultures (Sandler \& Keynan, 1981). If this relationship has physiological relevance, cell wall synthesis must precede initiation of DNA synthesis in this system. Measurements of GlcNAc incorporation and initiation of DNA replication as functions of time in such cultures have shown this to be the case. A stationary-phase culture of $B$. subtilis was diluted with fresh medium to induce synchronous renewal of growth as above, and the capacity of portions of the culture to incorporate $\left[{ }^{14} \mathrm{C}\right] \mathrm{GlcNAc}$, or to incorporate $\left[{ }^{3} \mathrm{H}\right]$ thymidine in the presence of CAM, was measured at intervals from the beginning of incubation.

More than $90 \%$ of the $\left[{ }^{14} \mathrm{C}\right]$ GlcNAc incorporation was blocked by vancomycin, a specific inhibitor of cell wall synthesis (Reynolds, 1966), indicating that the measured incorporation was into cell wall. Inhibition of protein synthesis by CAM also effectively prevented incorporation of $\left[{ }^{14} \mathrm{C}\right]$ GlcNAc by the cells (Fig. $4 a$ ).

The capacity of the cells to incorporate $\left[{ }^{14} \mathrm{C}\right] \mathrm{GlcNAc}$ increased before initiation of DNA replication, defined as acquisition of the capacity to synthesize DNA in the presence of CAM (Fig. 4b).

\section{Effect of inhibitors and low temperature on association of DNA with membrane fraction 2}

The association of DNA with membrane fraction 2 prior to initiation of replication was prevented by substances which inhibit initiation under the conditions of our experiments, including the protein synthesis inhibitor CAM (Fig. 5), the cell wall synthesis inhibitor vancomycin (Fig. 6), and bacitracin, another inhibitor of cell wall synthesis. Lowering the temperature of the culture to $4{ }^{\circ} \mathrm{C}$ delayed initiation of DNA replication by at least $40 \mathrm{~min}$, and delayed association of DNA with fraction 2 by about 20 min (data not shown). At low temperature, the separation in time between association of DNA with membrane fraction 2 and initiation of DNA replication was especially clear (data not shown).

\section{Association of externally added DNA with membrane fraction 2}

The addition of excess labelled bacterial DNA to a membrane sonicate before fractionation did not lead to appreciable association of label with fraction 2 . Approximately $1 \times 10^{6} \mathrm{c} . \mathrm{p} . \mathrm{m}$. of 


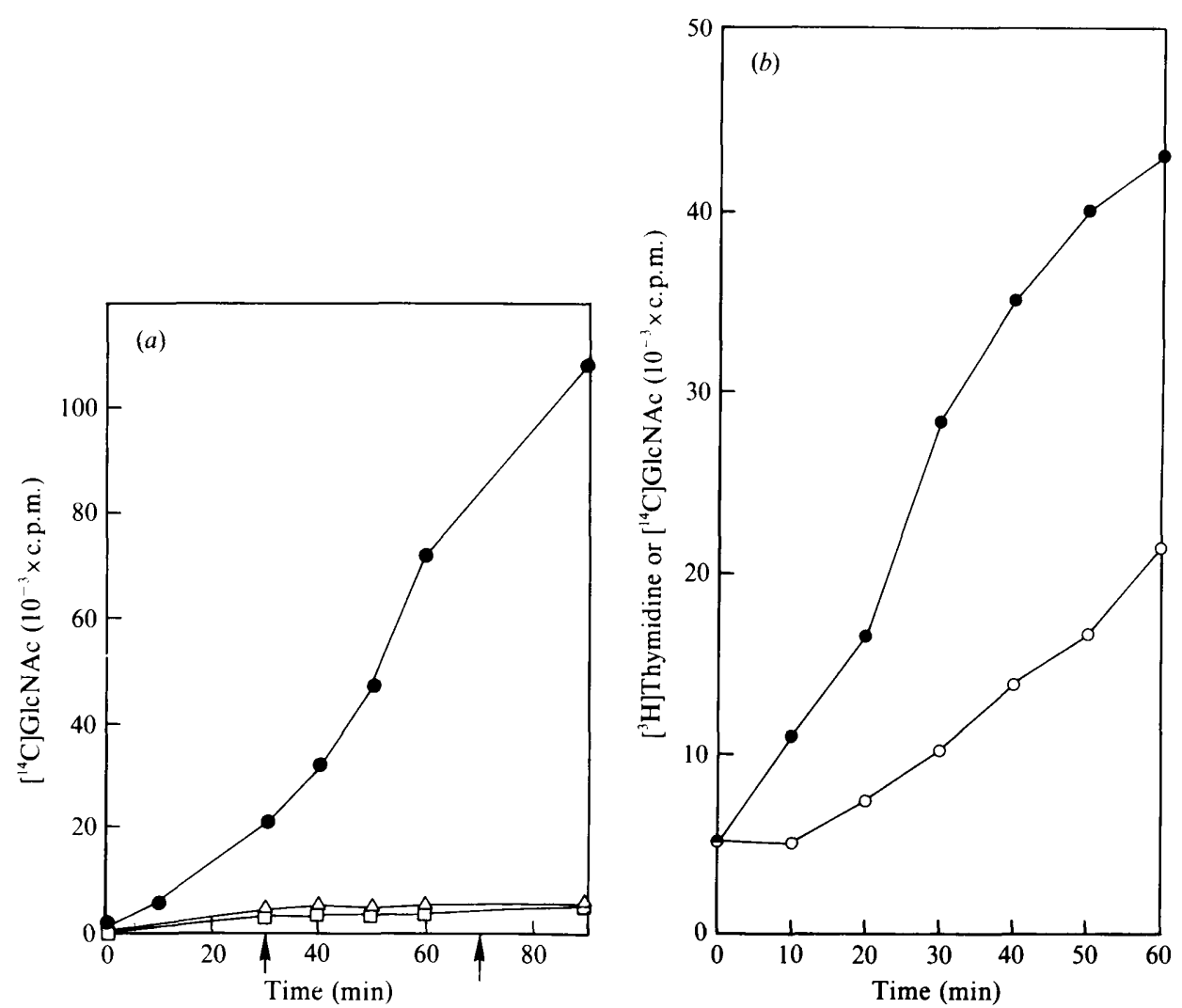

Fig. 4. (a) Incorporation of GIcNAc into cell wall. A stationary-phase culture was diluted 1 in 4 with fresh $\mathrm{BHI}$ and divided into four equal portions for incubation at $37^{\circ} \mathrm{C}$. $\left[{ }^{3} \mathrm{H}\right.$ ]Thymidine was added to one of the flasks and samples removed at intervals for measurement of incorporation of label into DNA in the presence of CAM. Arrows indicate peaks of incorporation. $\left[{ }^{14} \mathrm{C}\right] \mathrm{GlcNA}$. was added to the remaining flasks and incorporation was determined in the control $(\odot)$, in the presence of $100 \mu \mathrm{g} C A M$ $\mathrm{ml}^{-1}(\triangle)$, and in the presence of $3 \mu \mathrm{g}$ vancomycin $\mathrm{ml}^{-1}(\square)$.

(b) Cell cycle dependence of the rate of incorporation of GicNAc. A stationary-phase culture was diluted 1 in 4 with fresh $\mathrm{BHI}$ and incubated at $37^{\circ} \mathrm{C}$. Portions were removed at 10 min intervals for determination of initiation of DNA replication measured as incorporation of $\left[{ }^{3} \mathrm{H}\right]$ thymidine in the presence of CAM during $120 \mathrm{~min}(\mathrm{O})$, or for measurement of $\left[{ }^{14} \mathrm{C}\right] \mathrm{GlcNAc}$ incorporation during $10 \min (O)$.

${ }^{32} \mathrm{P}$-labelled $B$. subtilis chromosomal DNA was added to a ${ }^{3} \mathrm{H}$-labelled membrane preparation containing approximately $7 \times 10^{6}$ c.p.m. prior to sonication and fractionation. The ratio of ${ }^{32} \mathrm{P}$ to ${ }^{3} \mathrm{H}$ counts eluted in membrane fraction 2 was less than $2: 100$, compared with an initial ratio of about $14: 100$.

Effect of lytic enzymes on association of DNA with membrane fraction 2

Treatment of a sonicated membrane preparation with proteinase $\mathrm{K}$ before fractionation led to loss of most of the DNA radioactivity from membrane fraction 2 compared to results obtained with an untreated control (data not shown), indicating that the association is mediated by protein.

Treatment of membrane fractions with S1 DNAase prior to agarose gel electrophoresis led to disappearance of a diffuse band of fast-migrating ethidium-bromide-stained material. A slowermoving band containing more DNA was not affected. The diffuse band was not removed by digestion with pancreatic RNAase, suggesting that at least some of the membrane-fraction- 


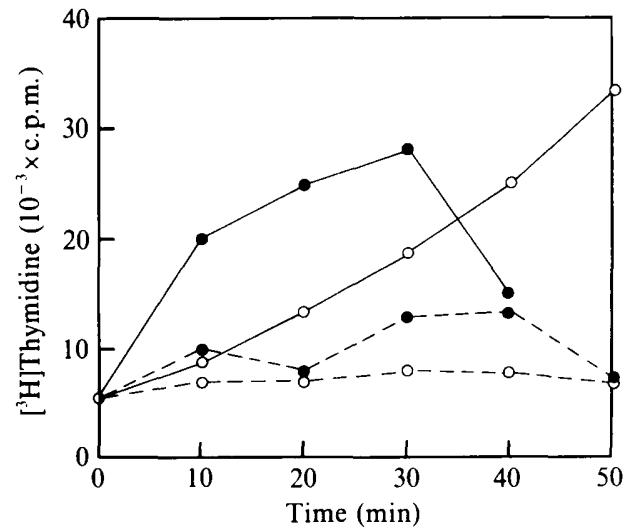

Fig. 5

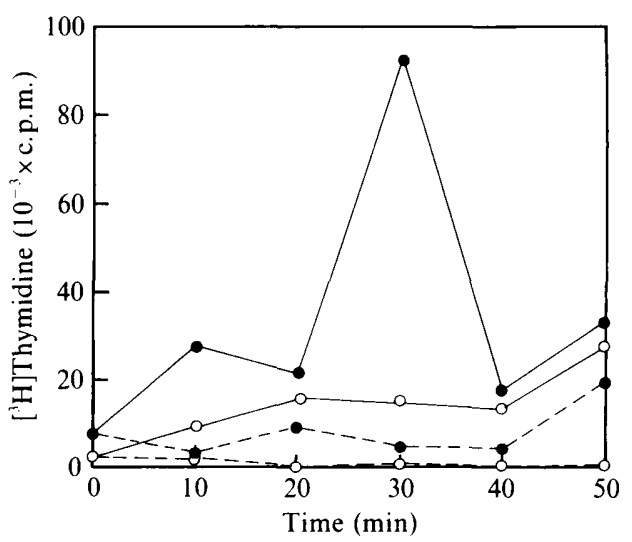

Fig. 6

Fig. 5. Effect of CAM on association of DNA with membrane fraction 2. A stationary-phase culture pre-labelled with $\left[{ }^{3} \mathrm{H}\right]$ thymidine as described in the legend to Fig. 2 was diluted 1 in 10 with fresh BHI and divided into three equal portions. Two portions were incubated at $37^{\circ} \mathrm{C}$ and samples removed at intervals for determination of radioactivity associated with membrane fraction $2(O)$, and measurement of incorporation of $\left[{ }^{3} \mathrm{H}\right]$ thymidine in the presence of CAM, as described in Methods $(O)$. - , Control; ---, culture to which CAM $\left(100 \mu \mathrm{g} \mathrm{ml}^{-1}\right)$ was added at the beginning of incubation. The third portion was transferred to a water bath at $4{ }^{\circ} \mathrm{C}$ and treated in the same way as the first two portions.

Fig. 6. Effect of vancomycin on the association of DNA with membrane fraction 2. A stationary-phase culture pre-labelled with $\left[{ }^{3} \mathrm{H}\right]$ thymidine as described in the legend to Fig. 2 was diluted 1 in 10 with fresh $\mathrm{BHI}$, divided into two equal portions, and incubated at $37^{\circ} \mathrm{C}$ with no additions $(-)$ or in the presence of $3 \mathrm{mg}$ vancomycin $\mathrm{ml}^{-1}(--)$. At intervals after the start of incubation, samples were removed for determination of radioactivity associated with membrane fraction $2(\bigcirc)$ and measurement of incorporation of $\left[{ }^{14} \mathrm{H}\right]$ thymidine in the presence of CAM as described in Methods $(\mathrm{O})$.

bound DNA was in single-stranded form. However, the apparent presence of single-stranded DNA may be an artifact due to damage caused by sonication.

\section{Proteins associated with membrane fraction 2}

Analysis by PAGE of the proteins associated with four-times-fractionated membrane fraction 2 revealed four major bands corresponding approximately to molecular masses of 45 , 50,58 and $66 \mathrm{kDa}$ (data not shown).

\section{DISCUSSION}

Daniels (1971) found DNA associated with a fraction of the Bacillus cytoplasmic membrane of lipid composition $85 \%$ phosphatidylethanolamine, $13 \%$ phosphatidic acid and $2 \%$ cardiolipin, and of density $1.092 \mathrm{~g} \mathrm{ml}^{-1}$. We adapted his method for measurement of the DNA associated with membrane fractions prepared from synchronous cultures of $B$. subtilis during the cell cycle. We observed a cyclic association of early-replicating DNA with certain components of the cytoplasmic membrane. Preliminary experiments (data not shown) indicated that sequences included in an $8 \mathrm{~kb}$ fragment from the $B$. subtilis replication origin region are associated with membrane fraction 2 at the time of peak DNA-membrane association and are also present to at least some extent at the time of minimal association. Further experiments are now in progress to determine the relative amounts of origin DNA in association with membrane fraction 2 as a function of the cell cycle, and to identify other sequences which may be involved in the cyclic DNA-membrane association.

Many previous studies have been based on the affinity of sarcosyl for membrane lipids. Crabb et al. (1980) compared eukaryotic membrane-DNA complexes binding to sarcosyl with complexes isolated by centrifugation in a Renografin gradient. The complexes isolated by the 
two methods were found to be similar. Binding to sarcosyl apparently does not alter the natural configuration of the DNA-membrane complex of $B$. subtilis, since such complexes are able to initiate DNA replication in vitro (Benjamin \& Firshein, 1983).

Cyclic binding of DNA replication origins during the cell cycle was observed when the sarcosyl method was used to analyse nuclear membrane binding of DNA from Chinese hamsters (Hildebrand \& Tobey, 1973) or HeLa cells (Yamada \& Hanaoka, 1973).

We observed that some previously synthesized DNA was transiently associated with a membrane fraction of a specific lipid composition (Daniels, 1971) on initiation of DNA replication, and that as replication began, newly synthesized DNA replaced old DNA associated with this membrane region. The association of DNA with membrane regions was apparently mediated by protein. Since early replicating DNA is involved in the binding, it is possible that the sequences of DNA in the vicinity of the replication origin identified by Sargent $\&$ Bennett $(1985,1986)$ as points of membrane attachment may be involved in this cell-cycledependent DNA association.

At initiation of replication, the two strands of the existing chromosome separate when each becomes the template for synthesis of its complementary strand. Exchange of 'old' and 'new' label associated with this membrane region would occur if only one of the existing strands, with its newly forming complement, remained bound to this region, while the other existing strand was released immediately after initiation of replication. Exchange of label would also be observed if strand separation in the region of the origin is maintained during initiation of replication, and both newly synthesized DNA strands replaced both existing strands in association with this membrane region. The latter possibility implies the presence of singlestranded DNA in the membrane-fraction-bound material. We are unable to distinguish between these alternative explanations on the basis of the available data.

We have reported that initiation of DNA replication is dependent on the process of cell wall synthesis when cell growth is renewed in stationary-phase cultures of B. subtilis (Sandler \& Keynan, 1981). This conclusion was based on the finding that arresting wall synthesis prevented normal initiation of DNA replication. As described above, we have confirmed that the rate of incorporation of peptidoglycan precursor into the cells increased prior to initiation of DNA replication in our system. Since there is no known contact between the wall-synthesis apparatus and DNA other than via the cytoplasmic membrane, we were interested to determine whether inhibition of cell wall synthesis, preventing initiation of DNA replication, acts by affecting the binding of origin DNA to the cytoplasmic membrane.

The prevention of DNA binding to membrane components by inhibitors of cell wall synthesis, as described in this report, is consistent with the hypothesis that this binding is the point at which these inhibitors block initiation of DNA replication.

\section{REFERENCES}

Benjamin, P. \& Firshein, W. (1983). Initiation of DNA replication in vitro by a DNA-membrane complex extracted from Bacillus subtilis. Proceedings of the National Academy of Sciences of the United States of America 80, 6214-6218.

Bone, E. J., Todd, J. A., Ellar, D. J., Sargent, M. G. \& WYKeS, A. W. (1985). Membrane particles from Escherichia coli and Bacillus subtilis, containing penicillin-binding proteins and enriched for chromosomal origin DNA. Journal of Bacteriology 164, 192200.

Budman, D. R. \& Pardee, A. B. (1967). Thymidine and thymine incorporation into deoxyribonucleic acid: inhibition and repression by uridine of thymidine phosphorylase of Escherichia coli. Journal of Bacteriology 94, 1546-1550.

Crabb, W. D., Firshein, W. \& Infante, A. A. (1980). A potential DNA replication complex isolated from sea urchin embryos by Renografin gradient centrifugation. Biochimica et biophysica acta 609, 456463.

DANIELs, M. J. (1971). Some features of the bacterial membrane studied with the aid of a new fractionation technique. Biochemical Journal 122, 197-207.

Doyle, R. J., Steips, U. N., IMADA, S., FAN, V. S. C. \& Brown, E. C. (1980). Genetic transformation with cell wall-associated deoxyribonucleic acid in Bacillus subtilis. Journal of Bacteriology 144, 957-966.

Fielding, P. \& Fox, C. F. (1970). Evidence for stable attachment of DNA to membrane at the replication origin of Escherichia coli. Biochemical and Biophysical Research Communications 415, 157-162.

Hildebrand, C. E. \& TobEY, R. A. (1973). Temporal organization of DNA in Chinese hamster cells : cellcycle dependent association of DNA with membrane. Biochimica et biophysica acta 331, 165-180. 
JaCOB, F., Brenner, S. \& CUZin, F. (1963). On the regulation of DNA replication in bacteria. Cold Spring Harbor Symposia on Quantitative Biology 28, 329-348.

LARK, K., RePKo, T. \& HoffMan, E. (1963). The effect of amino acid deprivation on subsequent deoxyribonucleic acid replication. Biochimica et biophysica acta 76, 9-24.

Maniatis, T., Fritsch, E. F. \& Sambrook, J. (1982). Molecular Cloning, a Laboratory Manual. Cold Spring Harbor, NY: Cold Spring Harbor Laboratory.

Masters, M., Kuempel, P. L. \& Pardee, A. (1964). Enzyme synthesis in synchronous cultures of bacteria. Biochemical and Biophysical Research Communications 15, 38-42.

Nicolaidis, A. A. \& Holland, I. B. (1978). Evidence for the specific association of the chromosomal origin with outer membrane fractions isolated from Escherichia coli. Journal of Bacteriology 135, 178-189.

PAulton, R. J. L. (1971). The synchronization of Bacillus subtilis by the relaxation of a division control system. Canadian Journal of Microbiology 17, 178189.

REYNOLDS, P. E. (1966). Antibiotics affecting cell-wall synthesis. Symposia of the Society for General Microbiology 16, 47-69.

SANDleR, N. \& Keynan, A. (1979). Changes in sporulation potential during the growth cycle of Bacillus subtilis. Archives of Microbiology 123, 9-14.

SANDlER, N. \& Keynan, A. (1981). Cell wall synthesis and initiation of deoxyribonucleic acid replication in Bacillus subtilis. Journal of Bacteriology 148, 443-449.

SARGENT, M. G. \& BENNETT, M. F. (1985). Amplification of a major membrane-bound DNA sequence of Bacillus subtilis. Journal of Bacteriology 161, 589-595.

SARGENT, M. G. \& BENNETT, M. F. (1986). Identification of a specific membrane-particle-associated DNA sequence in Bacillus subtilis. Journal of Bacteriology 166, 38-43.
SARGENT, M. G., BenNetT, M. F. \& BuRdeTt, I. D. J (1983). Identification of specific restriction fragments associated with a membrane subparticle from Bacillus subtilis. Journal of Bacteriology 154, 13891396.

SNYDER, R. W. \& Young, F. E. (1969). Association between the chromosome and the cytoplasmic membrane in Bacillus subtilis. Biochemical and Biophysical Research Communications 35, 354-362.

SuEOKA, N. \& QuinN, W. G. (1968). Membrane attachment of the chromosome replication origin in Bacillus subtilis. Cold Spring Harbor Symposia on Quantitative Biology 33, 695-705.

Tremblay, G. Y., Daniels, M. J. \& Schaechter, M. (1969). Isolation of a cell membrane-DNA-nascent RNA complex from bacteria. Journal of Molecular Biology 40, 65-70.

Winston, S. \& SUEOKA, N. (1980). DNA-membrane association is necessary for initiation of chromosomal and plasmid replication in Bacillus subtilis. Proceedings of the National Academy of Sciences of the United States of America 77, 2834-2838.

Winston, S. \& SUEOKA, N. (1982). DNA replication in Bacillus subtilis. In The Molecular Biology of the Bacilli, vol. 1, pp. 36-69. Edited by D. A. Dubnau. New York: Academic Press.

Yamada, M. \& HaNaOKA, F. (1973). Periodic changes in the association of mammalian DNA with the membrane during the cell cycle. Nature New Biology 43, 227-230.

Yamaguchi, K., MuraKami, S. \& Yoshikawa, H. (1971). Chromosome-membrane association in Bacillus subtilis. Biochemical and Biophysical Research Communications 44, 1559-1565.

Yoshikawa, H. \& Sueoka, N. (1963). Sequential replication of Bacillus subtilis chromosome. II. Isotopic transfer experiments. Proceedings of the National Academy of Sciences of the United States of America 49, 806-813. 